Article

\title{
A Framework of Unsustainable Behaviors to Support Product Eco-Design
}

\author{
Anil Balikci ${ }^{1,2}$, Yuri Borgianni ${ }^{2, *} \mathbb{C}$, Lorenzo Maccioni ${ }^{2}\left(\mathbb{D}\right.$ and Chiara Nezzi ${ }^{2}$ \\ 1 Independent Researcher, Mersin 33010, Turkey; balikcianil@outlook.com \\ 2 Faculty of Science and Technology, Free University of Bozen-Bolzano, 39100 Bolzano, Italy; \\ lorenzo.maccioni@unibz.it (L.M.); chiara.nezzi@unibz.it (C.N.) \\ * Correspondence: yuri.borgianni@unibz.it; Tel.: +39-047-101-7821
}

Citation: Balikci, A.; Borgianni, Y.;

Maccioni, L.; Nezzi, C. A Framework of Unsustainable Behaviors to Support Product Eco-Design. Sustainability 2021, 13, 11394. https:/ / doi.org/10.3390/su132011394

Academic Editor: Adriana Del Borghi

Received: 17 September 2021

Accepted: 13 October 2021

Published: 15 October 2021

Publisher's Note: MDPI stays neutral with regard to jurisdictional claims in published maps and institutional affiliations.

Copyright: (c) 2021 by the authors. Licensee MDPI, Basel, Switzerland. This article is an open access article distributed under the terms and conditions of the Creative Commons Attribution (CC BY) license (https:// creativecommons.org/licenses/by/ $4.0 /)$.

\begin{abstract}
Eco-designed products can contribute to sustainable development if consumers choose them rather than the less environmentally friendly alternatives and if they are used properly. However, eco-design methods have so far failed to address the issue of unsustainable behaviors, whose sources have not been recognized. In light of this deficiency, the authors have analyzed a large number of eco-designed products with the aim to capture the possible unsustainable behaviors arising from their use and consumption. The subsequent characterization of unsustainable behaviors has led to the creation of a framework of unsustainable behaviors, which has been subjected to the evaluation of a pool of experts in the field. In its final version, the framework includes nine classes of unsustainable behaviors, which are categorized into the corresponding product lifecycle phases (purchase, use, end of life), and different kinds of undesired effects (harmful, insufficient, excessive) based on the TRIZ-oriented functional analysis. The classes, whose significance has been checked in the literature, include frequent causes of unsustainable behaviors and corresponding examples. Through the framework, designers can take into due account the possible circumstances that would prevent their developed products from being prone to unsustainable behaviors. In a future step, the classes of unsustainable behaviors are to be linked with indications arising from Design for Sustainable Behavior.
\end{abstract}

Keywords: unsustainable behaviors; design for sustainable behavior; eco-design; design strategies; product development; product lifecycle; TRIZ; design requirements

\section{Introduction and Background}

Eco-design supports designers in taking into account sustainable aspects during all phases of the products' life cycle [1]. However, a major criticality of eco-design is the real effectiveness of the developed sustainable products. Those often fail to satisfy customers' requirements and needs, and hence they do not truly contribute to sustainable development due to their scarce market penetration [2]. This has emerged clearly in a recent discussion held during the webinar organized on 30 September 2021 by the Design Society's Special Interest Groups "Sustainable Design" and "Design Process", which targeted the design science's contribution towards the United Nations' Sustainable Development Goal 12 "Responsible Consumption and Production". It was particularly highlighted that while design contribution to responsible production is evident and acknowledged, its support to the pursuance of sustainable consumption is questionable. Consequently, (eco-) design methodologies and science suffer from shortcomings when it comes to addressing the mentioned Sustainable Development Goal.

Markedly, mainstream eco-design methods tend to overlook factors that might jeopardize actual advantages in terms of sustainability [3-5] despite the potential goodness of eco-designed products (EDPs). Among those factors, the role of unsustainable people's behaviors can be mentioned. Taking into account the unsustainable behaviors (UBs) a person may exhibit or a product may be subjected to is critical to effectively developing 
sustainable products. Markedly, human behaviors in relation to products can strongly influence (negatively) sustainable development [6]. As the present study addresses UBs displayed by users and consumers towards products, the focus is on people's actions that are currently not controlled or supervised by producers, manufacturers, and providers. These UBs and actions are here considered irrespective of the specific methods, principles, and strategies used to come up with the development of EDPs, such as Circular Economy, cradle-to-cradle or Product-Service Systems. It follows that the UBs considered here do not include designers', industrialists', and manufacturers' failure or reluctance to adopt proven models and methods for sustainable development. The boundaries of studied UBs will be further clarified in Section 2.1 .

In this context, various studies on how to steer users' behaviors have been conducted. Therefore, designers and researchers have started to focus on Design for Sustainable Behavior (DfSB), which may be addressed as a complementary thread with respect to eco-design [7]. Several sources [8-14] document the triggers of development, outreach, diffusion, and theoretical background of DfSB, along with approaches sharing the same goals while possibly differing in terminology.

According to [6], DfSB targets the design of solutions that, not only exhibit a lower environmental harmfulness, but also prompt modifications of perspective users' interactions with the developed products, which results in modifying their behavior towards sustainable goals. In other terms, DfSB does not simply focus on the environmental impact of products, but also aims to understand how and why that product might affect the sustainable habits of a consumer. In this area of research, a tenet is that modifying consumers' behaviors through design is viable. Consequently, conceptual studies mostly focused on the illustration of strategies for steering behavior changes.

According to [10], strategies for DfSB investigate possible behavioral changes by means of different frameworks, namely schemes and methodologic drivers to understand and categorize sustainable behaviors. A variety of frameworks are available in the literature and an overview of the salient concepts is useful for the scope of this paper. A firstly introduced approach [7] based the induction of sustainable behaviors on the adaptation of behaviors and the specific design to trigger sustainable use. The framework they developed presents three strategies characterized by different magnitudes of intervention to steer sustainable behaviors: (i) Feedback, providing consumers with information about the environmental consequences of their behaviors; (ii) scripting products to induce sustainable use; and (iii) forcing, in order to avoid unsustainable behaviors. Overall, the most notable frameworks for DfSB focus on this three-strategy set, differing primarily in terms of terminology, granularity level, outreach of the strategies, and explanations provided to illustrate what the strategies include. For instance, strategy (iii) is redefined as persuasive technology in [15], which tends to change customers' behaviors, sometimes without their full consent or awareness. The authors in [16] establish phases to inform, maintain, and force the change [12], similarly to [7]. A further expansion of this framework can be found in [17], which proposes a subdivision of the three main strategies, according to the user's power in decision-making. The authors in [8] propose a slightly different framework, which has the scope of influencing and forcing sustainability in users' behaviors based on eleven strategies. Other and more recent attempts of developing different frameworks can be found in $[18,19]$, but the common thread is simply represented by proposing and classifying actions, practices, measures, and principles to make people's behavior more sustainable.

Although DfSB is well established to indicate how to induce sustainable behaviors as stated in various review papers [10,12], some research gaps can still be found, especially when it comes to capitalizing on DfSB knowledge in eco-design.

The mentioned adherence to the three-strategy framework calls into question the comprehensiveness of the presented DfSB approaches. Otherwise said, as the developed models have been substantially based on a reference framework, it can be questioned whether the three strategies along with their expansions and specifications can address all possible problems in terms of UBs due to the use, possession of, and interaction with 
products. This limitation might then result in missing design principles to steer customers' behaviors in a number of circumstances.

An additional weakness is represented by the lack of guidance in the use of DfSB strategies in a product design process. The starting point for the application of DfSB strategies is rather a psychologic trigger or need in some cases, e.g., [20]. Most of the contributions in the area of DfSB provide brilliant examples of design changes viable to change people's behaviors and possibly reduce the environmental footprint. No process has been developed that logically links a problem to solve or a requirement to fulfil with principles, methods or approaches [6], which are necessary steps in design processes and product development. On the one hand, this calls into question effectiveness issues, as DfSB strategies are consequently applied unsystematically. In this regard, many authors additionally claim the severity of these problems and the simultaneous lack of studies to verify the real effectiveness of DfSB strategies adopted, e.g., [21]. The problem is partially alleviated when DfSB approaches are applied in User-Centered Design tasks, e.g., [22-24], since individuals are more directly involved in the design process. On the other hand, the limited guidance shown by DfSB in design processes highlights the need to identify and define which problems can be actually solved with the strategies and suggestions included in the above frameworks. These strategies seem of general applicability and have the overall ambition of educating people towards being sustainable and acting sustainably. Therefore, it is unsurprising how many DfSB examples deal with the systems used and handled by public institutions to push the adoption of environment-aware, respectful, and healthy behaviors, see, e.g., the examples provided in [25]. However, less is known about the strategies' appropriateness to correct or prevent the misuse of products and consumer goods with negative environmental consequences, which might be largely the result of poor awareness or knowledge of what is actually more sustainable [3], wrong perceptions [26] or unwitting actions. In this respect, it emerges how the identification and characterization of UBs may represent the stepping-stone to a better integration of DfSB in (eco-) design.

The need to consider UBs beyond inducing sustainable behaviors is specifically stressed in [10], which identifies this aspect as a relevant weakness in DfSB research. The authors in [27] highlight the issue of identifying conditions for unwanted behaviors. In [28], the authors point out that enhancing sustainability within customers' actions should also primarily consider what is sustainable and unsustainable in an action. This aspect underlines the need for a thorough understanding of UBs and how those can be identified in the design process in order to apply DfSB strategies or new (eco-) design principles. The construction of a comprehensive framework of product-oriented UBs useful to design is the objective and main result of this paper.

\section{Materials and Methods}

In the present section, the process behind the development of a framework to classify UBs is presented. This framework, whose final version is presented in Section 3, has been developed and fine-tuned through multiple steps as illustrated in Figure 1, which clarifies the inputs and outputs of these different steps. First, the phases of the product life cycle where people's behavior could potentially be unsustainable were identified (Section 2.1). Second, the authors examined (in a brainstorming session) the potential criticalities (in terms of the effects of unsustainable behavior) of the EDPs described in [29]. The outcome of the brainstorming session has resulted in a preliminary framework that, in turn, has been evaluated by six eco-design experts (Section 2.2). The preliminary framework was modified based on the feedback received, and a final framework was then proposed (Section 2.3). This final version was evaluated by the same six eco-design experts. The feedback showed unanimous agreement in the framework's ability to comprehensively and consistently cover the various UBs a person may adopt and/or a product may be subjected to accordingly. 


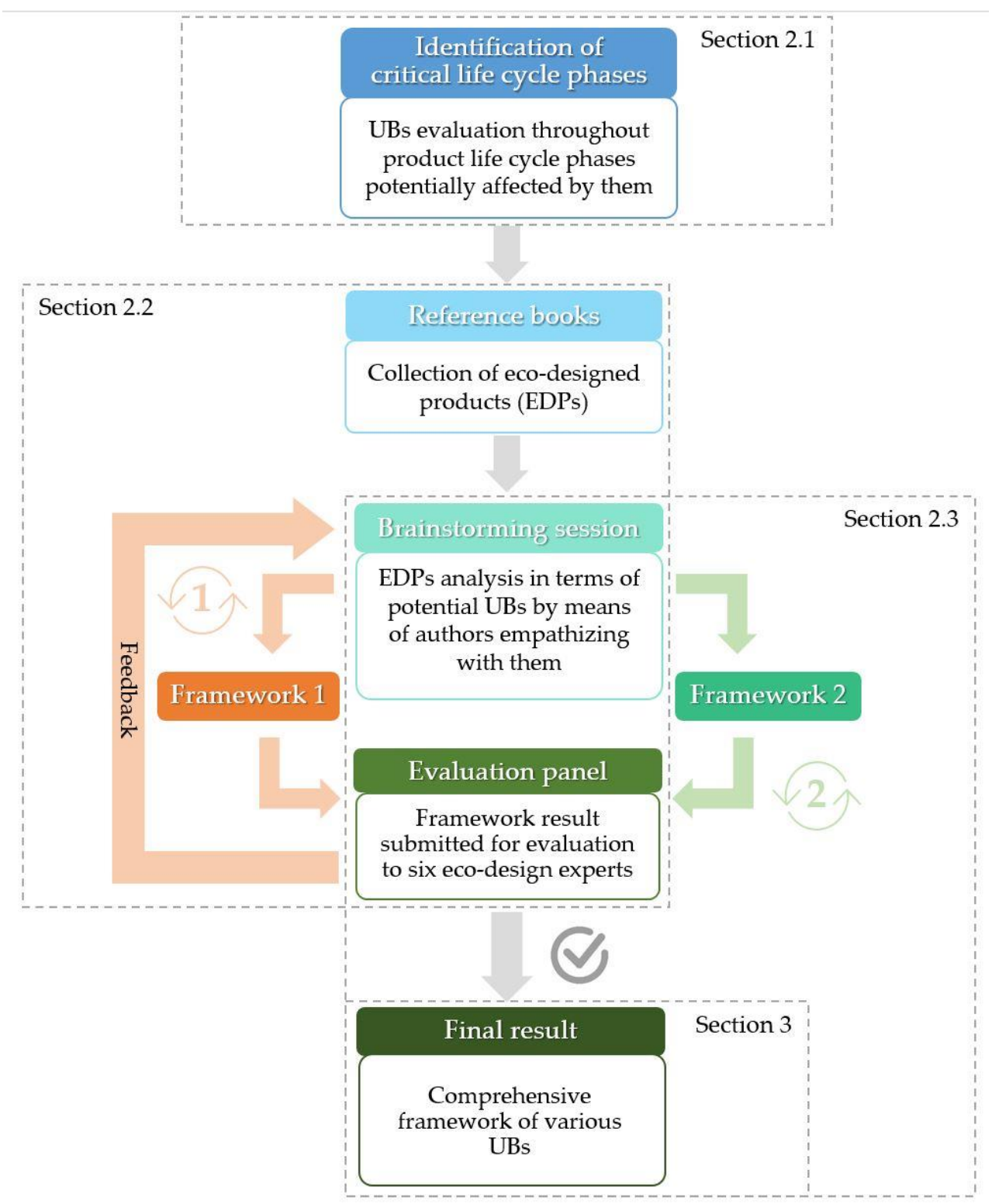

Figure 1. Methodological approach followed in the research.

2.1. Identification of the EDP Life Cycle Phases Where People's Behavior May Prove to Be a Barrier to the Expected Sustainability

In relation to the different product's life cycle phases, i.e., pre-production, production, distribution, use, and end-of-life (EOL), it is possible to identify when people's behavior could directly affect the EDP sustainability. The relevance of use and disposal are straightforward. People, markedly users or consumers, can use an EDP in a different way from the designed (optimal) one by actually misusing it. Therefore, if it occurs, the sustainable benefits potentially enabled by a new design are jeopardized [30]. On the other hand, with respect to the EOL phase, people could not dispose the EDP as required. Therefore, in this case, all of the potential environmental benefits from material selection and/or reusing, remanufacturing, recycling or composting processes are jeopardized [31]. In addition to use and EOL, numerous studies emphasize that the concept of sustainability necessarily includes the market success [3-5,9]. Indeed, an EDP that is not purchased (or exploited in case of service) cannot be considered sustainable [32]. In other words, a consumer could not purchase the EDP due to the fact that they prefer a less sustainable alternative to the EDP in question. Regardless of the reasons behind this consumers' choice, it is indisputable that, if an EDP is not purchased, all of the potentially sustainable advantages conceived during de- 
sign are ineffective. Therefore, since the purchase phase is a fundamental step (influenced by people's behavior) in determining the diffusion of the EDP, the authors considered it appropriate to add a further phase in the classic life cycle, i.e., the purchase phase.

Eventually, the EDP life cycle phases where peoples' behavior may be a barrier for achieving the expected sustainability are purchase, use, and EOL (Figure 2). The other phases, i.e., pre-production, production, and distribution, can be considered disjointed with respect to the people's behavior, since these phases are fully managed by design, production, and logistics.

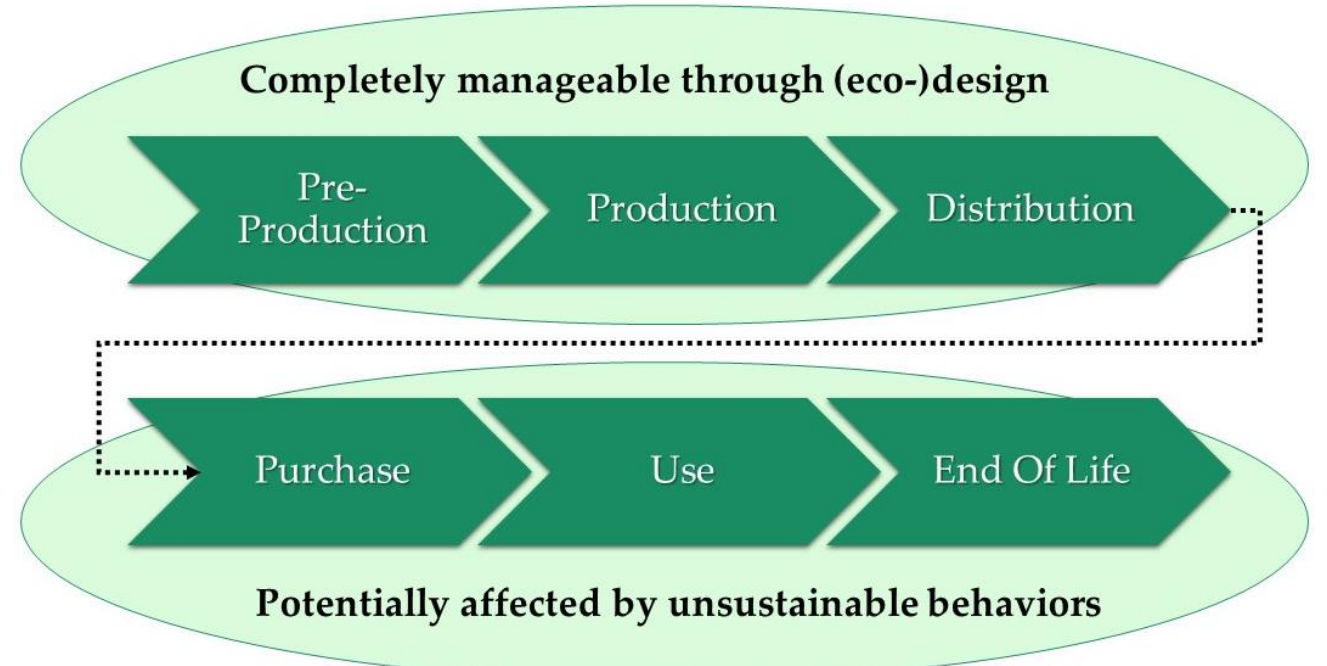

Figure 2. Life cycle phases potentially affected by unsustainable behaviors.

\subsection{Preliminary Characterization of Unsustainable Behaviors and Expert Evaluation}

"Design for environmental sustainability" [29] is a pillar reference in the sustainableand eco-design field. In this book, many EDPs have been illustrated to elucidate eco-design strategies and principles. However, although these products are good examples for the book's objective, they are not exempt from being affected by UBs. For instance, the Ikea air sofa has been exploited by the scholars as an illustrative example of dematerialization. However, it is acknowledged that this product was a fiasco [3]. On the same line, the scholars promote the car sharing as use-oriented eco-efficient Product-Service Systems. However, it is established that the user behavior has a determining role on the actual sustainability of the car sharing system, especially when it is preferred to public transport rather than the private car [33]. Therefore, the authors, during several brainstorming sessions, analyzed all of the products and eco-design examples shown in [29] and hypothesized reasonable UBs (and their causes) that might arise. In particular, the authors attempted to emphasize with products and played the role of users (lacking discipline and sustainability awareness). Therefore, the approach mirrored the persona model, frequently used in experience-based and sustainability-oriented design [34-36], markedly in the task of elucidating design requirements [37]. Here, the search for requirements had a limited focus on the product characteristics and circumstances that could engender UBs.

The UBs that emerged in the brainstorming sessions were abstracted and categorized according to the three stages of the life cycle. The result of this process led to the framework summarized in Appendix A. This framework has been sent to six eco-design experts from five different countries. The involvement of experts to evaluate classifications and lists of items for scientific purposes is the main milestone in research studies, as shown in [38]. In this study, the experts were invited to comment on this classification, especially in terms of those metrics that are critical to evaluating taxonomies based on the literature $[39,40]$, markedly: 
- Comprehensiveness, i.e., the capability of the classification in terms of covering the possible situations in which UBs dealing with products can be spotted;

- Consistency, coherence, i.e., the robustness of the classification, the extent to which the subdivision between classes is understandable and reasonable;

- Non-redundancy, i.e., the extent to which the classes do not overlap;

- Clarity.

Moreover, the evaluators have been urged to comment with respect to other issues they might have wanted to bring to the authors' attention.

All of the evaluators highlighted the originality and usefulness of classifying UBs for design scopes, but raised some concerns on the structure and the presentation of the first-attempt classification. Specifically, they highlighted that:

- With respect to comprehensiveness, the preliminary framework was not able to clearly capture the misuse of the product (intentional or unconscious). Moreover, the level of granularity of the preliminary framework has been questioned, since it was not able to cover UBs that could be manifested with services or Product-Service Systems;

- In terms of consistency and coherence, some terms adopted in this framework were evaluated as neither clear nor derived from systematic categorization. Moreover, it has been pointed out that the rebound effect is not a behavior, but a negative outcome of a behavior;

- Some classes resulted as insufficiently clear and others as partially overlapping. Moreover, adding practical examples to improve clarity was suggested.

\subsection{Fine-Tuning of the Final Framework}

Based on the raised criticism and specific suggestions provided by the eco-design experts, the framework was fine-tuned. First, a systematic method to characterize the undesired effects of the UBs has been applied. With this respect, the functional analysis proposed in the TRIZ methodology [41] has been exploited. TRIZ is the Russian acronym for the "Theory of Inventive Problem Solving" and, in practice, the TRIZ methodology proposes a series of tools for the identification and creative resolution of problems. The concept behind the functional analysis (as understood in TRIZ) is that different parts of a system interact through functions. The main goal of the system is to fulfil the main useful function. However, when a problem arises, other kinds of functions/effects are present. The undesired effects, such as UBs if a person is part of the analyzed system, can be classified in the following three groups, e.g., [42,43]:

- Harmful effects: Undesirable effects that adversely modify the system parameters;

- Insufficient effects: Effects that change the parameters of the system in the right direction but do not reach a satisfying threshold;

- Excessive effects: Effects that modify the parameters of the system in the right direction but in an excessive way. Therefore, this potentially generates new problems within the system or with different systems.

The new framework has been formulated by benefiting from the above categories of effects to target consistency, coherence, comprehensiveness, and non-redundancy. Therefore, this categorization has been added to the lifecycle considerations. Moreover, the classes achieved from the combination of lifecycle phases and categories of effects have been checked in terms of their actual relevance in the literature. The classes were enriched by possible causes of UBs in order to help identify the possible relevance of certain UBs for a product to be designed. Furthermore, the new framework has been enriched by explanatory (practical) examples to improve clarity, as suggested by the experts.

The final framework has been evaluated by the eco-design experts involved in the previous step. The structure of the framework along with the examples have been provided through a slideshow presentation. Based on the received feedback, no further changes to the classification and its presentation were requested. 


\section{Results: A Framework of Unsustainable Behaviors for Designs}

The UB classes and reference framework that emerged from the process described in the previous section is shown in Figure 3. In the figure, it has been emphasized that several barriers hinder the achievement of the level of sustainability envisioned in eco-design. The phases following the production and distribution processes where people's behavior can play a relevant role are purchase, use, and EOL (top of Figure 3). Moreover, in the phases prone to be affected by UBs, those can be classified according to the three types of undesired effects based on TRIZ (harmful, insufficient, and excessive), as highlighted in the left-hand side of the figure. The above-mentioned combination (relevant life phases and TRIZ undesired effects) gave rise to nine independent classes comprehensively categorizing different barriers to sustainability due to UBs. A more detailed description of these classes (potential causes of UBs are presented) is provided in the subsections included in Sections 3.1-3.3, where references indicate examples of UB categories and causes. Each of these subsections reports a class of UBs with the same description administered to the experts in the second (and final) evaluation round.

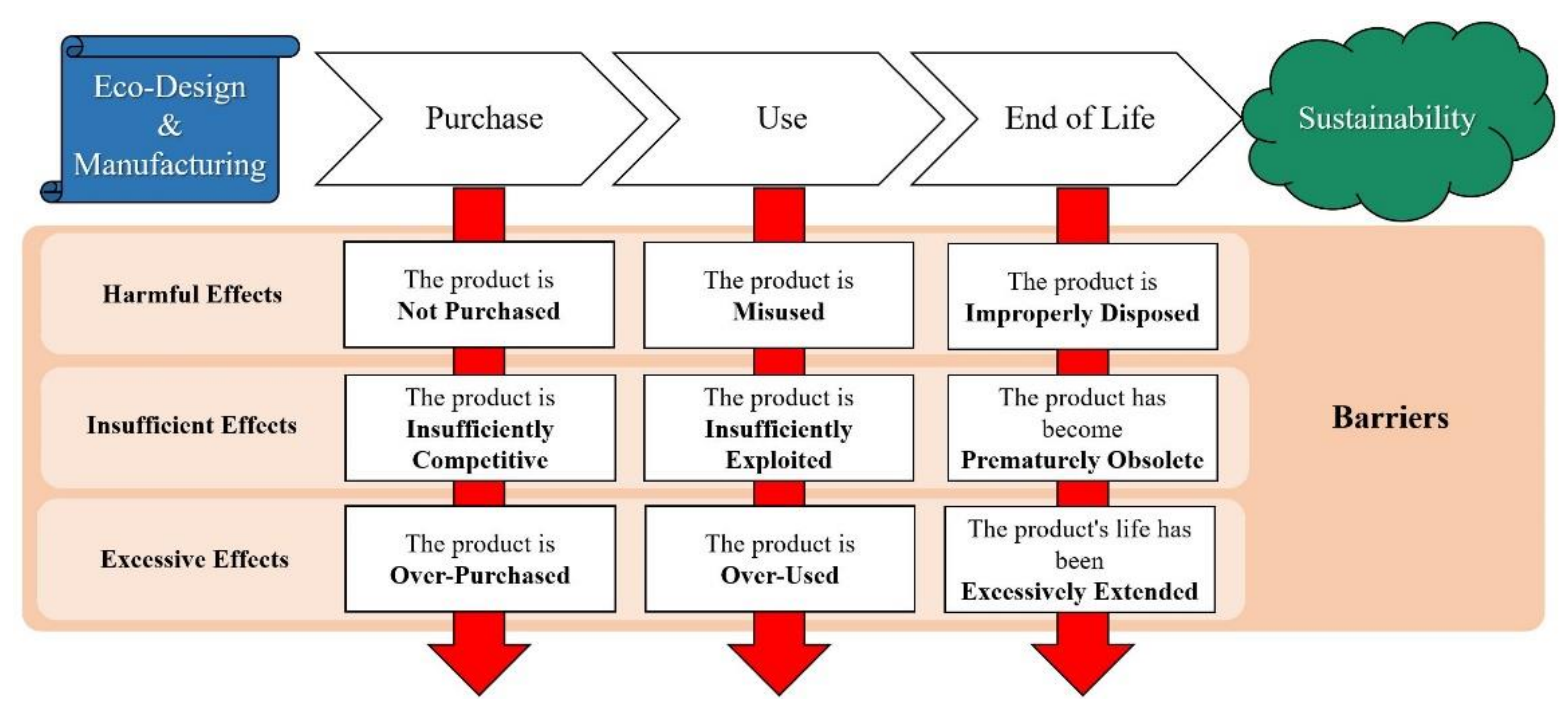

Figure 3. Proposed framework for mapping unsustainable behaviors affecting (eco-designed) products.

\subsection{UBs Potentially Emerging during the Purchase Phase}

3.1.1. The Product Is Not Purchased

The product could be not purchased, since the consumer prefers a less sustainable alternative to the product in question. The EDP is not (re)purchased, since the consumer does not perceive (has not perceived) its value and it can be considered a market failure. This may be due to the fact that the EDP does not achieve specific performance thresholds or it requires resources (in terms of time, money, space or information) that the consumer is not willing to sacrifice [44]. For example, the time required to refill a simple and cheap item such as a glue stick is not worthwhile in the user's view. One additional example can be related to edible packaging. Consumers can be aware of reducing waste. However, hygiene issues might be perceived by the users, as well.

The possible causes for this UB are listed below and additional details can be found in Appendix B, Table A4.

- $\quad$ The EDP exhibits missing or insufficient performances $[45,46]$;

- Additional time is required by the user, e.g., consumers need to learn how the EDP works or should be used [47];

- $\quad$ Costs are excessive $[48,49]$;

- $\quad$ The use or purchase of the EDP is bothering to some extent [45];

- New knowledge or skills have to be acquired and habits have to be changed [50,51]. 


\subsubsection{The Product Is Insufficiently Competitive}

The consumer buys the EDP. However, the EDP fails to replace the purchase (and therefore the use) of (at least) an alternative less sustainable product. This may be due to the fact that the EDP does not achieve specific performance thresholds. It can be considered a niche product or a product that replaces the less sustainable alternatives on a limited number of occasions only. A possible cause can be the lack of performances or presence of any issues that do not enable the full substitution of less sustainable alternatives [52,53]. For example, the manual washing machine or the solar cooker are two clear examples targeted by eco-design books that have not replaced traditional washing machines or cookers in peoples' life. Additional examples and clarifications on this category can be found in Appendix B, Table A5.

\subsubsection{The Product Is over Purchased}

The consumer buys the EDP, which is competitive with less sustainable alternatives. However, the superior performances of the EDP induce consumers to buy it even if they "do not need" it or they "do not need" an excessive quantity of it. A classic example exploited in eco-design books is the Lush solid shampoo, i.e., a shampoo that can be transported and used without packaging. The product is sustainable (reduced packaging) and original, and, as such appropriate for gifts. Therefore, when it is sold for gifts, a different kind of packaging and additional gadgets are usually included. An additional example can be related to 3D printing technologies. These enable a high level of customization with low material consumption. However, while they have become increasingly accessible, people have overexploited them by requesting objects that were not actually necessary. Two possible causes of this class of UBs are presented below and further details are provided in Appendix B, Table A6.

- Over purchase due to the high quality / price ratio of the EDP [54];

- Over purchase due to the creation of newly induced needs of the EDP [55].

\subsection{UBs Potentially Emerging during the Use Phase}

\subsubsection{The Product Is Misused}

The sustainable benefits potentially enabled by a new design are jeopardized in the fact that the user uses the EDP in a different way from the designed (optimal) one. An example may be related to concentrated detergents. They are considered more sustainable since they provide the same performance with decreased material use. However, it has been observed that many users tend to use the same amount of detergent they were used to (despite the fact that less would be sufficient). Overall, the possible sources of misuse are listed below, while support examples are reported in Appendix C, Table A7.

- The EDP is misused due to the lack of control and/or the user ignores the correct way of using it [56,57];

- The EDP is not correctly maintained [58];

- The EDP is misused due to being employed in the wrong context or for functions that it is not intended to perform [56,57].

\subsubsection{The Product Is Insufficiently Exploited}

The EDP fails to replace the use of (at least) an alternative less sustainable product or it is not exploited as expected when designed. For example, the iPod and MP3 players are often used as examples of dematerialization since they are able to contain the same hours of music that was previously contained on many CDs. However, these electronic devices have been used for a too limited time (due to the introduction of smartphones) to justify the substitution of previously used products. Their usage was too limited in time to be justified in terms of sustainability. The causes of this UB are listed below and additional clarifications can be found in Appendix C, Table A8. 
- Although the more sustainable product could be used in specific circumstances, the user keeps preferring a less sustainable alternative in some conditions [59];

- The users' needs get changed and/or they can be fulfilled in new ways and the EDP is not sufficiently exploited [60].

\subsubsection{The Product Is Overused}

The superior performances of the EDP induce the consumers to use it even if they "do not need" it to such an extent. For example, LED lightbulbs have a much lower energy consumption than the incandescent bulbs. Therefore, they can be kept switched on for longer times than needed, as the user is aware of their limited energy consumption. Another example can be related to the car sharing services, which are services providing a shared car fleet to customers, who pay for the kilometers of travel, for the time of use or for a mix of the two. Therefore, the car owner has an economic interest in providing efficient and non-polluting cars. In this case, users can benefit from this service rather than public transportation based on the advantages it provides, e.g., entering the town center. Overall, the possible causes behind the overuse are summarized below and additional examples can be found in Appendix C, Table A9.

- Overuse due to the perception of the low cost of the resources necessary for the operation of the EDP [61];

- Overuse due to the high quality/price ratio of the EDP [62].

\subsection{UBs Potentially Emerging during the End of Life}

3.3.1. The Product Is Improperly Disposed

The user does not dispose the EDP as required. Waste management policies are very important for sustainability. However, the disposal policies are not the same in every region/city. There are different disposal regulations for every region/city. When people are not informed clearly, they might not act as desired due to the lack of knowledge or their habits. In Appendix D, Table A10, the explanatory examples for this UB are reported.

- The product is difficult to be disassembled and materials cannot be easily separated [63];

- The user ignores or overlooks the correct way of disposing products $[31,64,65]$.

\subsubsection{The Product Has Become Prematurely Obsolete}

The EDP (or part of it) is discarded prior to the end of its useful (expected and/or technical) lifetime. For example, users might tend to substitute their PC prior to the end of its useful life, since they are attracted by rapidly increasing performances. The possible causes for this UB are listed below; additional clarifications can be found in Appendix D, Table A11.

- The product is perceived to be no longer competitive in terms of its technical performance [66-68];

- The product is perceived to be no longer competitive due to the changing (social) trends, fashion, and consumers' preferences $[69,70]$.

\subsubsection{The Product's Life Has Been Excessively Extended}

The EDP is not replaced by the latest eco-designed alternatives despite being obsolete. This may be due to the fact that the consumer is attached to the outdated EDP or due to the fact that buying a new EDP would require (monetary) resources that the consumer is not willing to sacrifice. For example, although a twenty-year-old car was designed following the eco-design guidelines of that time, it is not necessarily more sustainable than any car produced nowadays. It would be wise to change it if the overall impact suggests that. The users could get attached to their car and be reluctant to change it even it is no longer convenient from an environmental perspective. As a possible cause for this UB, the consumer is attached to the outdated product or would require (monetary) resources that 
they are not willing to sacrifice [71,72]. In Appendix D, Table A12, additional information is reported.

\section{Discussion and Conclusions}

\subsection{Main Findings and Comments}

Disregarding the possible effects of users' behavior in product development can jeopardize design efforts, especially when sustainability is dealt with. It is of anecdotal evidence that the misuse, mishandling or mismanagement of a product can cause undesired effects, such as harming the environment. Therefore, this issue is particularly relevant when eco-design processes are in place. Here, overlooking the fact that people are part of the system the product is integrated in can lead to unintended consequences and jeopardize the efforts made to sustainable product development. Actually, in a typical design process oriented to product development, the designer is expected to fulfil the previously identified requirements. If the requirements are not elicited, a design process, although carried out appropriately, cannot give rise to satisfactory outcomes. In this paper, the authors stress the need to consider the avoidance or minimization of UBs as part of the definition of design requirements. This is favored by the presented framework of UBs. A designer can actively use the framework as a checklist to identify which UBs the product under development can be subjected to. It is worth stressing that the creation of the framework proposed in this work represents the main original contribution of the present research. To the authors' best knowledge and state-of-the-art analysis, similar attempts to focus on and classify UBs for design purposes have not been made. Therefore, the authors lack any reference to compare the paper's findings with previous contributions.

The framework can be considered the missing link between the (eco-) design process and DfSB methods. Indeed, as pointed out in the introduction, DfSB methods tend to propose solutions without systematically supporting problem analysis. Through the proposed framework, the analysis of problems potentially arising due to UBs is systematically supported. In addition, from an educational perspective, the framework is useful for understanding the limitations of eco-design when UBs are in play. Through this framework, barriers in existing solutions can be highlighted and new design challenges can be formulated.

While the main benefits arising from the development of the illustrated framework of UBs lie in the design field, the general understanding of UBs related to products clearly represents a contribution beyond design. Overall, all of the disciplines potentially dealing with UBs can benefit from the presence of a framework, classification or taxonomy that have undergone a validation process. In particular, while the field of DfSB has been seldom subjected to studies investigating the exhaustiveness of related concepts, e.g., principles and strategies, the authors have targeted the achievement of a comprehensive framework. The capability of DfSB strategies to cope with the UBs elucidated in the present paper will represent a possible litmus test for DfSB comprehensiveness.

\subsection{Limitations and Future Work}

The connection between classes and causes of UBs (seen as potential problems) and design principles addressing them is indeed the most important future work envisioned by the authors. A current limitation of the present work is actually the fact that the framework currently supports the identification of significant issues related to (eco-designed) products, but no means for overcoming them are provided. Therefore, future research will be conducted to identify suitable design actions in relation to people's behavior, thus largely following in the footsteps of [73].

Other future research and limitations are worth mentioning. As for the former, the authors are willing to use their findings to consider the potential impact of UBs onproducts' environmental assessments. Markedly, Life Cycle Assessment, seen as a reference for systems' environmental sustainability, is criticized for its limited consideration of how humans might affect it [74]. Moreover, a potential new field of study opened up by the 
present research is represented by the investigation of alternatives to DfSB in addressing design problems related to UBs. In this respect, a possibility is represented by TRIZ, which, in addition to its acknowledged problem-solving capabilities, has proven effective in categorizing UBs. Moreover, it is worth noting that TRIZ originates from the engineering field, but its use is increasingly common for problems involving environmental sustainability, value aspects, and the humanities in general [44,75-82], which represent a clear reference for this study.

With regards to methodological limitations, it has to be pointed out that the procedure to verify the framework is affected by subjectivity despite the attempts to implement standards for scientific validation. This is unfortunately common to all the processes where human judgement is involved. Eventually, a content-oriented limitation can be viewed in the current failure to include the magnitude of negative effects produced by the different classes of UBs in the study. As design requirements are often prioritized in design tasks, it would be useful to understand whether some classes or causes are to be targeted first. Nevertheless, following the TRIZ classification of undesired effects, it can be hypothesized that harmful effects can also be the most detrimental in the domain of UBs.

Author Contributions: Conceptualization, Y.B. and L.M.; methodology, A.B.; validation, A.B., Y.B., L.M. and C.N.; formal analysis, A.B.; investigation, A.B. and C.N.; data curation, A.B. and L.M.; writing-original draft preparation, L.M. and C.N.; writing-review and editing, Y.B.; supervision, L.M. and Y.B.; funding acquisition, Y.B. All authors have read and agreed to the published version of the manuscript. The authors are listed in alphabetic order.

Funding: This work was supported by the Open Access Publishing Fund of the Free University of Bozen-Bolzano.

Institutional Review Board Statement: Not applicable.

Informed Consent Statement: Not applicable.

Data Availability Statement: Not applicable.

Acknowledgments: The study has been conducted in the framework of the project "fine-tuning new and smart ECO-design guidelines"(few sECOnds), funded by the Free University of Bozen-Bolzano (Bolzano, Italy).

Conflicts of Interest: The authors declare no conflict of interest.

\section{Appendix A. Preliminary Framework}

Table A1. Preliminary framework related to the barriers that could be manifested during the purchase phase.

\begin{tabular}{ccc}
\hline Category of Unsustainable Behavior & Definition & $\begin{array}{c}\text { Illustrative Examples, Additional } \\
\text { Explanations, Typical Causes }\end{array}$ \\
\hline Missing value aspects & $\begin{array}{c}\text { The consumer might be tempted to } \\
\text { relinquish the purchase of the product } \\
\text { because some expected benefits are not } \\
\text { delivered by the product or are not } \\
\text { perceived as such }\end{array}$ & $\begin{array}{c}\text { Scepticism about the product's capability of } \\
\text { delivering some benefits; questioned } \\
\text { integrity of the product, for instance during } \\
\text { transportation in case of reduced packaging }\end{array}$ \\
Need for sacrifice & $\begin{array}{c}\text { The consumer might be tempted to } \\
\text { relinquish the purchase of the product } \\
\text { because some sacrifices are needed or } \\
\text { perceived as such }\end{array}$ & $\begin{array}{c}\text { Excessive costs; long-term agreements to be } \\
\text { met; additional operations to be carried out }\end{array}$ \\
\hline Difficulties to identify value & $\begin{array}{c}\text { The consumer might be tempted to } \\
\text { relinquish the purchase of the product } \\
\text { because advantages are unclear or require a } \\
\text { change of habits }\end{array}$ & $\begin{array}{c}\text { Design modifications are not made sense of; } \\
\text { advantages, including those in sustainable } \\
\text { terms, cannot be figured out }\end{array}$ \\
\hline
\end{tabular}


Table A2. Preliminary framework related to the barriers that could be manifested during the use phase.

\begin{tabular}{|c|c|c|}
\hline $\begin{array}{l}\text { Category of Unsustainable } \\
\text { Behavior }\end{array}$ & Definition & $\begin{array}{l}\text { Illustrative Examples, Additional } \\
\text { Explanations, Typical Causes }\end{array}$ \\
\hline $\begin{array}{l}\text { Use of excessive material or energy } \\
\text { (product itself) }\end{array}$ & $\begin{array}{l}\text { The sustainable benefits ensuing from design are } \\
\text { jeopardized in that the user uses excessive material } \\
\text { (in case of consumable products) or energy }\end{array}$ & $\begin{array}{l}\text { The product is not used in the energy-save mode; the } \\
\text { amount of the consumed product exceeds the real } \\
\text { necessities, for instance due to previous habits }\end{array}$ \\
\hline $\begin{array}{l}\text { Use of excessive material or } \\
\text { energy (auxiliary) }\end{array}$ & $\begin{array}{l}\text { The sustainable benefits ensuing from design are } \\
\text { jeopardized in that the user uses excessive } \\
\text { additional auxiliary materials or resources to make } \\
\text { the product work }\end{array}$ & $\begin{array}{l}\text { The product is not used in a way that minimizes the } \\
\text { consumption of external supplementary } \\
\text { consumables; the user buys unneeded accessories }\end{array}$ \\
\hline $\begin{array}{l}\text { Rebound effects; overuse or } \\
\text { over-purchase }\end{array}$ & $\begin{array}{l}\text { The user is aware of the product's superiority in } \\
\text { terms of sustainability/cheapness and tends to } \\
\text { overuse it or buy it in a larger quantity }\end{array}$ & $\begin{array}{c}\text { The product engenders over-induced needs; the } \\
\text { product is used more frequently than necessary, } \\
\text { which can jeopardize previously more sustainable } \\
\text { habits }\end{array}$ \\
\hline Lack of maintenance & $\begin{array}{l}\text { The user does not carry out planned or needed } \\
\text { maintenance }\end{array}$ & $\begin{array}{l}\text { The maintenance activities are cumbersome and } \\
\text { considered not worthwhile }\end{array}$ \\
\hline
\end{tabular}

Table A3. Preliminary framework related to the barriers that could be manifested during the end of life phase.

\begin{tabular}{|c|c|c|}
\hline $\begin{array}{l}\text { Lack of incentive for not } \\
\text { buying an alternative } \\
\text { product }\end{array}$ & $\begin{array}{l}\text { The experience with the product does } \\
\text { not prevent the purchase of less } \\
\text { sustainable alternative products }\end{array}$ & $\begin{array}{l}\text { The user is not satisfied with the product and interrupts its use; the } \\
\text { product becomes obsolescent, for instance in terms of fashion trends; } \\
\text { the user does not get used to changing their habits to benefit from the } \\
\text { product adequately }\end{array}$ \\
\hline $\begin{array}{l}\text { Unexploited product } \\
\text { duration }\end{array}$ & $\begin{array}{l}\text { The product is discarded prior to the } \\
\text { end of its useful life }\end{array}$ & $\begin{array}{l}\text { The product is discarded because of unexpected sacrifices, lack of } \\
\text { comfort or convenience, obsolescence, unwillingness to change habits }\end{array}$ \\
\hline Wrong disposal & $\begin{array}{l}\text { The user does not dispose the product } \\
\text { as required }\end{array}$ & $\begin{array}{l}\text { The product is difficult to be disassembled and materials cannot be } \\
\text { easily separated; the user ignores the correct way of disposing products }\end{array}$ \\
\hline No repurchase & $\begin{array}{l}\text { The user does not repurchase the } \\
\text { product }\end{array}$ & $\begin{array}{c}\text { The product is not repurchased because of unexpected sacrifices, lack of } \\
\text { comfort or convenience, obsolescence, unwillingness to change habits; } \\
\text { the user is not satisfied and prefers previously experienced (and less } \\
\text { sustainable) alternative products }\end{array}$ \\
\hline
\end{tabular}

Please notice that the term "product" is used in this appendix in a broad sense and includes artefacts, tangibles, services, product-service-systems or other outcomes of design processes.

\section{Appendix B. Unsustainable Behaviors That Could Be Manifested during the Purchase Phase}

Table A4. Examples for clarifying the candidate causes of unsustainable beahavior when the product is not purchased.

\begin{tabular}{|c|c|c|c|}
\hline $\begin{array}{l}\text { Candidate Causes of } \\
\text { Unsustainable Behavior }\end{array}$ & Example & $\begin{array}{l}\text { Reasons behind the } \\
\text { Product Sustainability }\end{array}$ & $\begin{array}{l}\text { Possible Reasons behind the } \\
\text { Unsustainable Behavior }\end{array}$ \\
\hline $\begin{array}{l}\text { The EDP exhibits missing or } \\
\text { insufficient performances. }\end{array}$ & $\begin{array}{c}\text { Edible } \\
\text { packaging }\end{array}$ & $\begin{array}{l}\text { Packaging that is designed to be } \\
\text { eaten or has the ability to } \\
\text { biodegrade efficiently like the food } \\
\text { that it contains. }\end{array}$ & $\begin{array}{l}\text { The consumer can be aware of } \\
\text { reducing waste, however hygiene } \\
\text { issues might be perceived by the user } \\
\text { as well. }\end{array}$ \\
\hline $\begin{array}{l}\text { Additional time is required by the } \\
\text { user, e.g., consumers need to learn } \\
\text { how the EDP works or should } \\
\text { be used. }\end{array}$ & $\begin{array}{l}\text { Refillable } \\
\text { glue stick }\end{array}$ & $\begin{array}{l}\text { The mechanism can be used } \\
\text { permanently by changing the tape. }\end{array}$ & $\begin{array}{l}\text { The time required to refill a simple } \\
\text { and cheap item such as the glue stick } \\
\text { is not worthwhile in the user's view. }\end{array}$ \\
\hline Costs are excessive. & $\begin{array}{l}\text { Whirlpool } \\
\text { Green Kitchen }\end{array}$ & $\begin{array}{l}\text { A futuristic design that proposes to } \\
\text { reduce water and heat consumption. }\end{array}$ & $\begin{array}{l}\text { Not only this green kitchen was too } \\
\text { expensive, but it required } \\
\text { accessory costs. }\end{array}$ \\
\hline $\begin{array}{l}\text { The use or purchase of the EDP is } \\
\text { bothering to some extent. }\end{array}$ & $\begin{array}{c}\text { FRIA } \\
\text { by Ursula Tischner }\end{array}$ & $\begin{array}{l}\text { A fridge that uses cold outside air in } \\
\text { order to reduce energy } \\
\text { consumption. }\end{array}$ & $\begin{array}{l}\text { The kitchen and room should be } \\
\text { fully rearranged. }\end{array}$ \\
\hline $\begin{array}{l}\text { New knowledge or skills have to } \\
\text { be acquired; habits have to } \\
\text { be changed. }\end{array}$ & $\begin{array}{l}\text { Beauty Kitchen } \\
\text { Return-Refill-Reuse }\end{array}$ & $\begin{array}{l}\text { The consumer is responsible with } \\
\text { returning product (the container) so } \\
\text { that the company can re-use it and } \\
\text { reduce waste. }\end{array}$ & $\begin{array}{l}\text { The consumer might prefer another } \\
\text { product because of lack of confidence } \\
\text { to use and manage the system } \\
\text { as required. }\end{array}$ \\
\hline
\end{tabular}


Table A5. Examples for clarifying the candidate causes of unsustainable beahavior when the product is insufficiently competitive.

\begin{tabular}{|c|c|c|c|}
\hline $\begin{array}{l}\text { Candidate Causes of } \\
\text { Unsustainable Behavior }\end{array}$ & Example & $\begin{array}{l}\text { Reasons behind the } \\
\text { Product Sustainability }\end{array}$ & $\begin{array}{l}\text { Possible Reasons behind the } \\
\text { Unsustainable Behavior }\end{array}$ \\
\hline \multirow{3}{*}{$\begin{array}{l}\text { Lack of performances or } \\
\text { presence of any issues that } \\
\text { do not enable the full } \\
\text { substitution of less } \\
\text { sustainable alternatives. }\end{array}$} & $\begin{array}{l}\text { Car pooling, } \\
\text { e.g., Bla Bla Car }\end{array}$ & $\begin{array}{l}\text { It is a mode of transportation } \\
\text { that consists of sharing private } \\
\text { cars among a group of people, } \\
\text { with the main purpose of } \\
\text { reducing transportation costs } \\
\text { and environmental impact. }\end{array}$ & $\begin{array}{l}\text { The user knows that it is better to } \\
\text { share the journey in terms of } \\
\text { environment and costs, but } \\
\text { previous delays and bad } \\
\text { experiences with unknown people } \\
\text { the journey has been shared with } \\
\text { make users refrain from diffusely } \\
\text { benefitting from car pooling. }\end{array}$ \\
\hline & $\begin{array}{l}\text { Mechanically powered } \\
\text { products, e.g., flash lights, } \\
\text { trimmers or hand-tools }\end{array}$ & $\begin{array}{l}\text { These tools use hand power } \\
\text { instead of batteries. These } \\
\text { EDP are required to be } \\
\text { powered before using (In } \\
\text { general, with low usage time } \\
\text { or performance). }\end{array}$ & $\begin{array}{l}\text { Mainly technical aspects might } \\
\text { drive the consumer to purchase a } \\
\text { less sustainable product as well. }\end{array}$ \\
\hline & Solar cooker & $\begin{array}{l}\text { A cooker that works with the } \\
\text { solar power instead of gas. }\end{array}$ & $\begin{array}{l}\text { Limited usage time could lead the } \\
\text { customer to the less sustainable } \\
\text { (more traditional) alternatives. }\end{array}$ \\
\hline
\end{tabular}

Table A6. Examples for clarifying the candidate causes of unsustainable beahavior when the product is over-purchased.

\begin{tabular}{|c|c|c|c|}
\hline $\begin{array}{l}\text { Candidate Causes of } \\
\text { Unsustainable Behavior }\end{array}$ & Example & $\begin{array}{l}\text { Reasons behind the } \\
\text { Product Sustainability }\end{array}$ & $\begin{array}{l}\text { Possible Reasons behind the } \\
\text { Unsustainable Behavior }\end{array}$ \\
\hline \multirow{2}{*}{$\begin{array}{l}\text { Over purchase due to the high } \\
\text { quality/price ratio of the } \\
\text { (eco-designed) product }\end{array}$} & 3D printing services & $\begin{array}{l}\text { Additive manufacturing } \\
\text { technologies enable a high level } \\
\text { of customization with low } \\
\text { material consumption. }\end{array}$ & $\begin{array}{l}\text { While they have become } \\
\text { increasingly accessible, people have } \\
\text { overexploited them by requesting } \\
\text { objects that were not } \\
\text { actually necessary. }\end{array}$ \\
\hline & Dopper Bottle Water & $\begin{array}{c}\text { Reusable water bottles made by } \\
\text { plastic, glass and steel in order } \\
\text { to reduce the single used plastic } \\
\text { water consumption and } \\
\text { promoting the tap water usage. }\end{array}$ & $\begin{array}{l}\text { Due to its advertisements, } \\
\text { accessibility, and product range, } \\
\text { one might want to have more } \\
\text { products than actual requirements. }\end{array}$ \\
\hline \multirow{2}{*}{$\begin{array}{l}\text { Over purchase due to the } \\
\text { creation of newly induced } \\
\text { needs of the } \\
\text { eco-designed product }\end{array}$} & Lush solid shampoo & $\begin{array}{l}\text { Solid shampoo so that a } \\
\text { traditional packaging is } \\
\text { not necessary. }\end{array}$ & $\begin{array}{l}\text { The product is sustainable (reduced } \\
\text { packaging) and original, and, as } \\
\text { such appropriate for gifts. When } \\
\text { sold for gifts, a different kind of } \\
\text { packaging and additional gadgets } \\
\text { are included. }\end{array}$ \\
\hline & $\begin{array}{l}\text { Electric pushed } \\
\text { scooters }\end{array}$ & $\begin{array}{l}\text { In many cities, electric pushed } \\
\text { scooters are considered as } \\
\text { fundamental for the sustainable } \\
\text { mobility since they help reduce } \\
\text { cars exploitation. }\end{array}$ & $\begin{array}{l}\text { There have been initiatives that } \\
\text { have pushed their purchase, which } \\
\text { have resulted in replacing the use of } \\
\text { bicycles and public transportation, } \\
\text { and walking habits rather than cars. }\end{array}$ \\
\hline
\end{tabular}




\section{Appendix C. Unsustainable Behaviors That Could Be Manifested during the Use Phase}

Table A7. Examples for clarifying the candidate causes of unsustainable beahavior when the product is misused.

\begin{tabular}{|c|c|c|c|}
\hline $\begin{array}{l}\text { Candidate Causes of } \\
\text { Unsustainable Behavior }\end{array}$ & Example & $\begin{array}{l}\text { Reasons behind the } \\
\text { Product Sustainability }\end{array}$ & $\begin{array}{l}\text { Possible Reasons behind the } \\
\text { Unsustainable Behavior }\end{array}$ \\
\hline \multirow{4}{*}{$\begin{array}{l}\text { The EDP is misused because } \\
\text { of lack of control and/or the } \\
\text { user ignores the correct way } \\
\text { of using it }\end{array}$} & $\begin{array}{l}\text { Concentrated } \\
\text { detergent }\end{array}$ & $\begin{array}{l}\text { Concentrated detergents are considered } \\
\text { more sustainable because they provide the } \\
\text { same performance with less material use. }\end{array}$ & $\begin{array}{l}\text { The user uses the same amount of } \\
\text { detergent they were used to despite less } \\
\text { would be sufficient. }\end{array}$ \\
\hline & $\begin{array}{l}\text { Detergent-saving } \\
\text { washing machines }\end{array}$ & $\begin{array}{c}\text { Detergent-saving washing machine can } \\
\text { have the same performance with a lower } \\
\text { use of detergent. }\end{array}$ & $\begin{array}{c}\text { The user uses the same amount of } \\
\text { detergent they were used to despite less } \\
\text { would be sufficient. }\end{array}$ \\
\hline & $\begin{array}{l}\text { Enviro systems } \\
\text { E-cloth }\end{array}$ & $\begin{array}{l}\text { The E-cloth System is a housecleaning } \\
\text { cloth that, thanks to special microfibers, } \\
\text { cleans the surfaces (of glass, stainless steel, } \\
\text { chrome steel, etc.) without } \\
\text { chemical detergents. }\end{array}$ & $\begin{array}{l}\text { Although the product can work without } \\
\text { any additional materials (solvents, } \\
\text { detergents), consumers might still use } \\
\text { those due of habits or because they believe } \\
\text { additional materials enable } \\
\text { superior performances. }\end{array}$ \\
\hline & $\begin{array}{l}\text { Items integrating } \\
\text { solar chargers }\end{array}$ & $\begin{array}{l}\text { Solar-powered phone charger allows you } \\
\text { to use } 100 \% \text { solar energy to recharge } \\
\text { electronic devices instead of the energy } \\
\text { produced from other sources. }\end{array}$ & $\begin{array}{c}\text { The user might fail to load the charger } \\
\text { with its solar power option; instead, they } \\
\text { prefer traditional ways of } \\
\text { recharging devices. }\end{array}$ \\
\hline \multirow{2}{*}{$\begin{array}{l}\text { The EDP is not correctly } \\
\text { maintained }\end{array}$} & ADBlue & $\begin{array}{l}\text { Although the necessity of an additional } \\
\text { material usage is open to discussion, the } \\
\text { company claims that it is effective on } \\
\text { reducing } \mathrm{CO}_{2} \text { emission. }\end{array}$ & $\begin{array}{c}\text { The solvent reduces } \mathrm{CO}_{2} \text { emissions, but if } \\
\text { not regularly refilled by drivers, the car } \\
\text { usage gives rise to severe } \\
\text { environmental problems. }\end{array}$ \\
\hline & Solar panels & $\begin{array}{l}\text { Solar sourced systems require } \\
\text { maintenance in order to keep } \\
\text { the efficiency. }\end{array}$ & $\begin{array}{l}\text { Sustainable advantages are not achieved if } \\
\text { maintenance is not performed correctly. }\end{array}$ \\
\hline $\begin{array}{l}\text { The EDP is misused because } \\
\text { of being employed in the } \\
\text { wrong context or for functions } \\
\text { it is not intended to perform }\end{array}$ & $\begin{array}{c}\mathrm{A}+++ \\
\text { household appliances }\end{array}$ & $\begin{array}{l}\text { High performance households, for } \\
\text { example white goods, and claim less } \\
\text { energy consumption on specific operation. }\end{array}$ & $\begin{array}{l}\text { The user might tend to employ them in } \\
\text { wrong circumstances, also due to their } \\
\text { convenience, e.g., heating a plate in } \\
\text { the oven. }\end{array}$ \\
\hline
\end{tabular}

Table A8. Examples for clarifying the candidate causes of unsustainable beahavior when the product is insufficiently exploited.

\begin{tabular}{|c|c|c|c|}
\hline $\begin{array}{c}\text { Candidate Causes of } \\
\text { Unsustainable Behavior }\end{array}$ & Example & $\begin{array}{l}\text { Reasons behind the } \\
\text { Product Sustainability }\end{array}$ & $\begin{array}{l}\text { Possible Reasons behind the } \\
\text { Unsustainable Behavior }\end{array}$ \\
\hline \multirow{2}{*}{$\begin{array}{l}\text { Although the more } \\
\text { sustainable product could be } \\
\text { used in specific circumstances, } \\
\text { the user keeps preferring a } \\
\text { less sustainable alternative in } \\
\text { those conditions }\end{array}$} & Hybrid Cars & $\begin{array}{l}\text { The vehicles that have the option } \\
\text { to use fossil fuel or electricity. }\end{array}$ & $\begin{array}{l}\text { The user limits the use of electric cars to } \\
\text { downtown travelling, but they keep using } \\
\text { fuel cars for longer journeys. }\end{array}$ \\
\hline & $\begin{array}{l}\text { Water filters } \\
\text { and purifiers }\end{array}$ & $\begin{array}{l}\text { Filtration systems that allow the } \\
\text { user to filter or to purify the tap } \\
\text { water instead of getting } \\
\text { bottled water. }\end{array}$ & $\begin{array}{l}\text { The user might keep purchasing bottled } \\
\text { water instead of using filtered tap water, } \\
\text { for instance when they want to drink water } \\
\text { with gas, in presence of guests (offering tap } \\
\text { water is impolite in some countries). }\end{array}$ \\
\hline \multirow{2}{*}{$\begin{array}{l}\text { The users' needs get changed } \\
\text { and/or they can be fulfilled in } \\
\text { new ways and the EDP is not } \\
\text { sufficiently exploited }\end{array}$} & $\begin{array}{l}\text { Electronic } \\
\text { dictionary }\end{array}$ & $\begin{array}{l}\text { The electronic dictionary is often } \\
\text { used as an example of } \\
\text { dematerialization because it is } \\
\text { able to contain the same } \\
\text { information that was previously } \\
\text { printed on many kilograms } \\
\text { of paper. }\end{array}$ & $\begin{array}{l}\text { These electronic devices have been used for } \\
\text { a too limited time (because of introduction } \\
\text { of smartphones) to justify the substitution } \\
\text { of previously used sustainable products. } \\
\text { Their usage was too limited in time to be } \\
\text { justified in terms of sustainability. }\end{array}$ \\
\hline & $\begin{array}{l}\text { iPods } \\
\text { and MP3 } \\
\text { players }\end{array}$ & $\begin{array}{l}\text { The iPod and MP3players are } \\
\text { often used as examples of } \\
\text { dematerialization because they } \\
\text { are able to contain the same hours } \\
\text { of music that was previously } \\
\text { contained on many CD. }\end{array}$ & $\begin{array}{l}\text { These electronic devices have been used for } \\
\text { a too limited time (because of introduction } \\
\text { of smartphones) to justify the substitution } \\
\text { of previously used sustainable products. } \\
\text { Their usage was too limited in time to be } \\
\text { justified in terms of sustainability. }\end{array}$ \\
\hline
\end{tabular}


Table A9. Examples for clarifying the candidate causes of unsustainable beahavior when the product is over-used.

\begin{tabular}{|c|c|c|c|}
\hline $\begin{array}{l}\text { Candidate Causes of } \\
\text { Unsustainable Behavior }\end{array}$ & Example & $\begin{array}{l}\text { Reasons behind the } \\
\text { Product Sustainability }\end{array}$ & $\begin{array}{l}\text { Possible Reasons behind the } \\
\text { Unsustainable Behavior }\end{array}$ \\
\hline \multirow{2}{*}{$\begin{array}{l}\text { Overuse due to the perception } \\
\text { of the low cost of the } \\
\text { resources necessary for the } \\
\text { operation of the EDP }\end{array}$} & $\begin{array}{l}\mathrm{A}+++ \\
\text { TV sets }\end{array}$ & $\begin{array}{l}\text { A+++ TV sets have a much lower } \\
\text { energy consumption than their } \\
\text { competitors and also have a } \\
\text { furnishing function e.g., projecting } \\
\text { pictures or simulating fireplaces. }\end{array}$ & $\begin{array}{l}\text { They can be kept on for longer } \\
\text { times than needed, as the user } \\
\text { is aware of their limited } \\
\text { energy consumption. }\end{array}$ \\
\hline & LED lightbulbs & $\begin{array}{l}\text { LED lightbulbs have a much lower } \\
\text { energy consumption than } \\
\text { incandescent bulbs. }\end{array}$ & $\begin{array}{l}\text { They can be kept on for longer } \\
\text { times than needed, as the user } \\
\text { is aware of their limited } \\
\text { energy consumption. }\end{array}$ \\
\hline $\begin{array}{l}\text { Overuse due to the high } \\
\text { quality/price ratio of the EDP }\end{array}$ & Car sharing service & $\begin{array}{l}\text { They are services providing a } \\
\text { shared car fleet to the participants, } \\
\text { who pay for the kilometers of travel, } \\
\text { for the time of use or for a mix of } \\
\text { the two. Therefore, the car owner } \\
\text { has an economic interest in } \\
\text { providing efficient and } \\
\text { non-polluting cars. }\end{array}$ & $\begin{array}{l}\text { The user benefits from this } \\
\text { service instead of public } \\
\text { transportation, also based on } \\
\text { the advantages it provides, } \\
\text { e.g., entering the town center. }\end{array}$ \\
\hline
\end{tabular}

\section{Appendix D. Unsustainable Behaviors That Could Be Manifested during the End of Life Phase}

Table A10. Examples for clarifying the candidate causes of unsustainable beahavior when the product is improperly disposed.

\begin{tabular}{|c|c|c|c|}
\hline $\begin{array}{l}\text { Candidate Causes of } \\
\text { Unsustainable Behavior }\end{array}$ & Example & $\begin{array}{l}\text { Reasons behind the } \\
\text { Product Sustainability }\end{array}$ & $\begin{array}{c}\text { Possible Reasons behind the } \\
\text { Unsustainable Behavior }\end{array}$ \\
\hline $\begin{array}{l}\text { The product is difficult to be } \\
\text { disassembled and materials } \\
\text { cannot be easily separated }\end{array}$ & Electronic appliances & $\begin{array}{l}\text { Although an electronic device may be } \\
\text { designed to operate efficiently, if the } \\
\text { end of life of these components is not } \\
\text { managed properly the sustainable } \\
\text { benefits gained during its use may be } \\
\text { lost at the end of its life. }\end{array}$ & $\begin{array}{l}\text { Since electronic devices } \\
\text { consist of many different } \\
\text { types of materials and often } \\
\text { they are not designed to be } \\
\text { disassembled by the user, the } \\
\text { user might not follow the } \\
\text { proper disposal way. }\end{array}$ \\
\hline \multirow{2}{*}{$\begin{array}{c}\text { The user ignores or overlooks } \\
\text { the correct way of } \\
\text { disposing products }\end{array}$} & $\begin{array}{l}\text { Specific materials, e.g., } \\
\text { Tetrapak, bio-waste, } \\
\text { zinc-carbon batteries }\end{array}$ & $\begin{array}{c}\text { Waste management policies are very } \\
\text { important for sustainability. However, } \\
\text { the disposal policies are not same in } \\
\text { every region/city. }\end{array}$ & $\begin{array}{l}\text { There are different disposal } \\
\text { regulations for every } \\
\text { region/city. When people are } \\
\text { not informed clearly, they } \\
\text { might not act as desired due } \\
\text { to the lack of knowledge or } \\
\text { their habits. }\end{array}$ \\
\hline & $\begin{array}{l}\text { Multi-material } \\
\text { packaging, e.g., Mila } \\
\text { K3 Cap, food packages }\end{array}$ & $\begin{array}{l}\text { By leveraging different materials, } \\
\text { Mila has produced yogurt packaging } \\
\text { with a much better overall } \\
\text { environmental impact than plastic } \\
\text { packaging. However, the materials } \\
\text { have to be separated by the user at its } \\
\text { end of life. }\end{array}$ & $\begin{array}{l}\text { While reducing the plastic } \\
\text { content of the packaging and } \\
\text { substituting it with cardboard, } \\
\text { potential advantages are } \\
\text { turned into disadvantages if } \\
\text { the user throws everything in } \\
\text { the same recycle bin. }\end{array}$ \\
\hline
\end{tabular}


Table A11. Examples for clarifying the candidate causes of unsustainable beahavior when the product has become prematurely obsolete.

\begin{tabular}{|c|c|c|c|}
\hline $\begin{array}{l}\text { Candidate Causes of } \\
\text { Unsustainable Behavior }\end{array}$ & Example & $\begin{array}{l}\text { Reasons behind the } \\
\text { Product Sustainability }\end{array}$ & $\begin{array}{c}\text { Possible Reasons behind the } \\
\text { Unsustainable Behavior }\end{array}$ \\
\hline \multirow{2}{*}{$\begin{array}{l}\text { The product is perceived } \\
\text { to be no longer } \\
\text { competitive in terms of its } \\
\text { technical performance }\end{array}$} & ICT products, e.g., PCs & $\begin{array}{l}\text { The latest generations of ICTs are often } \\
\text { more sustainable than their predecessors. } \\
\text { However, to take full advantage of the } \\
\text { sustainable benefits they have to be used } \\
\text { for a minimum period of time. }\end{array}$ & $\begin{array}{l}\text { Users might tend to substitute } \\
\text { their PC prior to the end of its } \\
\text { useful life, because they are } \\
\text { attracted by rapidly } \\
\text { increasing performances. }\end{array}$ \\
\hline & Bio-degradable bags & $\begin{array}{l}\text { Biodegradable bags are more sustainable } \\
\text { than plastic ones and even these could be } \\
\text { reused to make the most of their } \\
\text { sustainable potential. }\end{array}$ & $\begin{array}{c}\text { They are commonly disposed } \\
\text { after a single usage although } \\
\text { they could perform } \\
\text { other functions. }\end{array}$ \\
\hline \multirow{2}{*}{$\begin{array}{l}\text { The product is perceived } \\
\text { to be no longer } \\
\text { competitive because of } \\
\text { changing (social) trends, } \\
\text { fashion, consumers' } \\
\text { preferences }\end{array}$} & $\begin{array}{l}\text { Electronic devices, e.g., } \\
\text { smartphones. }\end{array}$ & $\begin{array}{l}\text { The latest generations of smartphones are } \\
\text { often more sustainable than their } \\
\text { predecessors. However, to take full } \\
\text { advantage of the sustainable benefits they } \\
\text { have to be used for a minimum period } \\
\text { of time. }\end{array}$ & $\begin{array}{l}\text { Smartphones have fashion } \\
\text { aspect that exacerbate the } \\
\text { willingness of their too } \\
\text { early substitution. }\end{array}$ \\
\hline & $\begin{array}{l}\text { La sportiva shoes } \\
\text { with replaceable sole. }\end{array}$ & $\begin{array}{l}\text { La Sportiva offers a resoling service that } \\
\text { allows the initial quality of the shoes to } \\
\text { be regained. }\end{array}$ & $\begin{array}{l}\text { The user might prefer to } \\
\text { purchase another product } \\
\text { instead of using the possibility } \\
\text { of changing the sole of the } \\
\text { owned shoes. }\end{array}$ \\
\hline
\end{tabular}

Table A12. Examples for clarifying the candidate causes of unsustainable beahavior when the product's life has been excessively extended.

\begin{tabular}{|c|c|c|c|}
\hline $\begin{array}{l}\text { Candidate Causes of } \\
\text { Unsustainable Behavior }\end{array}$ & Example & $\begin{array}{l}\text { Reasons behind the } \\
\text { Product Sustainability }\end{array}$ & $\begin{array}{l}\text { Possible Reasons behind the } \\
\text { Unsustainable Behavior }\end{array}$ \\
\hline $\begin{array}{l}\text { The consumer is attached to } \\
\text { the outdated product or } \\
\text { would require (monetary) } \\
\text { resources that they are not } \\
\text { willing to sacrifice }\end{array}$ & $\begin{array}{l}\text { Most sustainable cars } \\
\text { (household appliances) } \\
\text { at the time of buying. }\end{array}$ & $\begin{array}{l}\text { Although a car (household appliance) } \\
\text { from } 20 \text { years ago was designed } \\
\text { following the eco-design guidelines } \\
\text { of that time, it is not necessarily more } \\
\text { sustainable than an eco-designed car } \\
\text { of today. It would be wise to change } \\
\text { it if the overall impact suggests so. }\end{array}$ & $\begin{array}{l}\text { The users get attached to their } \\
\text { car (household appliance) and } \\
\text { they are reluctant to change it } \\
\text { even it is no longer convenient } \\
\text { also from an } \\
\text { environmental perspective. }\end{array}$ \\
\hline
\end{tabular}

\section{References}

1. Ceschin, F.; Gaziulusoy, I. Evolution of design for sustainability: From product design to design for system innovations and transitions. Des. Stud. 2016, 47, 118-163. [CrossRef]

2. Skerlos, S.J. Promoting Effectiveness in Sustainable Design. Procedia CIRP 2015, 29, 13-18. [CrossRef]

3. Maccioni, L.; Borgianni, Y.; Pigosso, D.C.A. Can the choice of eco-design principles affect products' success? Des. Sci. $2019,5,25$. [CrossRef]

4. Maccioni, L.; Borgianni, Y.; Pigosso, D.C. Creativity in successful eco-design supported by ten original guidelines. Int. J. Des. Creativity Innov. 2021, 1-24. [CrossRef]

5. Montecchi, T.; Becattini, N. A MODELLING FRAMEWORK FOR DATA-DRIVEN DESIGN FOR SUSTAINABLE BEHAVIOUR IN HUMAN-MACHINE INTERACTIONS. In Proceedings of the Design Society; Cambridge University Press (CUP): Cambridge, UK, 2021; Volume 1, pp. 151-160.

6. Montecchi, T.; Becattini, N. DESIGN FOR SUSTAINABLE BEHAVIOR: OPPORTUNITIES AND CHALLENGES OF A DATADRIVEN APPROACH. In Proceedings of the Design Society: DESIGN Conference; Cambridge University Press (CUP): Cambridge, UK, 2020; Volume 1, pp. 2089-2098.

7. Wever, R.; van Kuijk, J.; Boks, C. User-centred design for sustainable behaviour. Int. J. Sustain. Eng. 2008, 1, 9-20. [CrossRef]

8. Tromp, D.M.; van Rheede, A.; Blomme, R.J. Low attention on the social dimension of sustainability in the hospitality industry: A Theoretical perspective. In Proceedings of the 3rd I-CHLAR Conference, Lyon, France, 7-8 July 2011. 
9. Macdonald, E.; She, J. Seven Cognitive Concepts for Successful Sustainable Design. In Proceedings of the Volume 4: 36th Mechanisms and Robotics Conference, Parts A and B, Chicago, IL, USA, 12-15 August 2012; Volume 45066, pp. 485-500.

10. Coskun, A.; Zimmerman, J.; Erbug, C. Promoting sustainability through behavior change: A review. Des. Stud. 2015, 41, 183-204. [CrossRef]

11. Niedderer, K.; Ludden, G.; Clune, S.; Lockton, D.; Mackrill, J.; Morris, A.; Hekkert, P. Design for behaviour change as a driver for sustainable innovation: Challenges and opportunities for implementation in the private and public sectors. Int. J. Des. 2016, 10, 67-85.

12. De Medeiros, J.F.; da Rocha, C.G.; Ribeiro, J.L.D. Design for sustainable behavior (DfSB): Analysis of existing frameworks of behavior change strategies, experts' assessment and proposal for a decision support diagram. J. Clean. Prod. 2018, 188, 402-415. [CrossRef]

13. Shin, H.D.; Bull, R. Three Dimensions of Design for Sustainable Behaviour. Sustainability 2019, 11, 4610. [CrossRef]

14. Giangrande, N.; White, R.M.; East, M.; Jackson, R.; Clarke, T.; Coste, M.S.; Penha-Lopes, G. A Competency Framework to Assess and Activate Education for Sustainable Development: Addressing the UN Sustainable Development Goals 4.7 Challenge. Sustainability 2019, 11, 2832. [CrossRef]

15. Lilley, D. Design for sustainable behaviour: Strategies and perceptions. Des. Stud. 2009, 30, 704-720. [CrossRef]

16. Bhamra, T.; Lilley, D.; Tang, T. Sustainable use: Changing consumer behaviour through product design. In Proceedings of the Changing the Change: Design Visions, Proposals and Tools, Turin, Italy, 10-12 July 2008.

17. Tang, T.; Bhamra, T. Putting consumers first in design for sustainable behaviour: A case study of reducing environmental impacts of cold appliance use. Int. J. Sustain. Eng. 2012, 5, 288-303. [CrossRef]

18. Irizar-Arrieta, A.; Casado-Mansilla, D.; Garaizar, P.; López-De-Ipiña, D.; Retegi, A. User perspectives in the design of interactive everyday objects for sustainable behaviour. Int. J. Hum.-Comput. Stud. 2020, 137, 102393. [CrossRef]

19. Shu, Y.; Ho, S.-J.; Huang, T.-C. The Development of a Sustainability-Oriented Creativity, Innovation, and Entrepreneurship Education Framework: A Perspective Study. Front. Psychol. 2020, 11, 1878. [CrossRef] [PubMed]

20. Zachrisson, J.L.D.; Boks, C. Exploring behavioural psychology to support design for sustainable behaviour research. J. Des. Res. 2012, 10, 50-66. [CrossRef]

21. Brynjarsdottir, H.; Håkansson, M.; Pierce, J.; Baumer, E.; DiSalvo, C.; Sengers, P. Sustainably unpersuaded. In Proceedings of the SIGCHI Conference on Human Factors in Computing Systems, Austin, TX, USA, 5-10 May 2012; pp. 947-956.

22. Froehlich, J.; Findlater, L.; Landay, J. The design of eco-feedback technology. In Proceedings of the 28th International Conference on Human Factors in Computing Systems-CHI '10, Atlanta, GA, USA, 10-15 April 2010; pp. 1999-2008.

23. Selvefors, A.; Pedersen, K.B.; Rahe, U. Design for sustainable consumption behaviour. In Proceedings of the 2011 Conference on Designing Pleasurable Products and Interfaces-DPPI '11, Milano, Italy, 22-25 June 2011; pp. 1-8.

24. Daae, J.; Boks, C. A classification of user research methods for design for sustainable behaviour. J. Clean. Prod. 2015, 106, 680-689. [CrossRef]

25. Scurati, G.W.; Carulli, M.; Ferrise, F.; Bordegoni, M. Sustainable Behaviour: A Framework for the Design of Products for Behaviour Change. In Emotional Engineering; Springer: New York, NY, USA, 2020; Volume 8, pp. 65-83.

26. Du Bois, E.; Veelaert, L.; Tormans, E.; Moons, I. HOW SHOULD PLASTIC RECYCLATES LOOK LIKE TO BE PERCEIVED AS SUSTAINABLE: A FIRST EXPLORATION. In Proceedings of the Design Society; Cambridge University Press (CUP): Cambridge, UK, 2021; Volume 1, pp. 1765-1774.

27. Hoolohan, C.; Browne, A. Design thinking for practice-based intervention: Co-producing the change points toolkit to unlock (un)sustainable practices. Des. Stud. 2020, 67, 102-132. [CrossRef]

28. Lockton, D.; Harrison, D.; Stanton, N.A. Design for Sustainable Behaviour: Investigating design methods for influencing user behaviour. Annu. Rev. Policy Des. 2016, 4, 1-10.

29. Vezzoli, C.; Manzini, E.; Tukker, A.; Charter, M.; Stø, E.; Andersen, M.M.; Vezzoli, C. Design for sustainable consumption and production systems. In System Innovation for Sustainability 1: Perspectives on Radical Changes to Sustainable Consumption and Production; Greenleaf Publishing: Sheffield, UK, 2008.

30. Wastling, T.; Charnley, F.; Moreno, M. Design for Circular Behaviour: Considering Users in a Circular Economy. Sustainability 2018, 10, 1743. [CrossRef]

31. Klug, K.; Niemand, T. The lifestyle of sustainability: Testing a behavioral measure of precycling. J. Clean. Prod. 2021, 297, 126699. [CrossRef]

32. Maccioni, L.; Borgianni, Y.; Basso, D. Value Perception of Green Products: An Exploratory Study Combining Conscious Answers and Unconscious Behavioral Aspects. Sustainability 2019, 11, 1226. [CrossRef]

33. Jung, J.; Koo, Y. Analyzing the Effects of Car Sharing Services on the Reduction of Greenhouse Gas (GHG) Emissions. Sustainability 2018, 10, 539. [CrossRef]

34. Carey, M.; White, E.J.; McMahon, M.; O'Sullivan, L.W. Using personas to exploit environmental attitudes and behaviour in sustainable product design. Appl. Ergon. 2019, 78, 97-109. [CrossRef] [PubMed]

35. Heck, J.; Rittiner, F.; Meboldt, M.; Steinert, M. Promoting user-centricity in short-term ideation workshops. Int. J. Des. Creativity Innov. 2018, 6, 130-145. [CrossRef]

36. Alvarez, J.; Léger, P.-M.; Fredette, M.; Chen, S.-L.; Maunier, B.; Senecal, S. An Enriched Customer Journey Map: How to Construct and Visualize a Global Portrait of Both Lived and Perceived Users' Experiences? Designs 2020, 4, 29. [CrossRef] 
37. Cascini, G.; Graziosi, S.; Montagna, F.; Rotini, F. On the Factors Affecting Design Education Within a Multi-Disciplinary Class. J. Integr. Des. Process. Sci. 2017, 21, 21-44. [CrossRef]

38. Cloquell-Ballester, V.-A.; Cloquell-Ballester, V.-A.; Monterde-Díaz, R.; Santamarina-Siurana, M.-C. Indicators validation for the improvement of environmental and social impact quantitative assessment. Environ. Impact Assess. Rev. 2006, 26, 79-105. [CrossRef]

39. Suwa, M.; Scott, A.C.; Shortliffe, E.H. An approach to verifying completeness and consistency in a rule-based expert system. Ai Mag. 1982, 3, 16. [CrossRef]

40. Sim, S.K.; Duffy, A.H.B. Towards an ontology of generic engineering design activities. Res. Eng. Des. 2003, 14, 200-223. [CrossRef]

41. Gadd, K. TRIZ for Engineers: Enabling Inventive Problem Solving; Wiley: Hoboken, NJ, USA, 2011.

42. Russo, D.; Duci, S. From Altshuller's 76 Standard Solutions to a New Set of 111 Standards. Procedia Eng. 2015, 131, 747-756. [CrossRef]

43. Fiorineschi, L.; Frillici, F.S.; Rotini, F.; Tomassini, M. Exploiting TRIZ Tools for enhancing systematic conceptual design activities. J. Eng. Des. 2018, 29, 259-290. [CrossRef]

44. Borgianni, Y.; Cardillo, A.; Cascini, G.; Rotini, F. Systematizing new value proposition through a TRIZ-based classification of functional features. Procedia Eng. 2011, 9, 103-118. [CrossRef]

45. Joshi, Y.; Rahman, Z. Consumers' Sustainable Purchase Behaviour: Modeling the Impact of Psychological Factors. Ecol. Econ. 2019, 159, 235-243. [CrossRef]

46. Rausch, T.M.; Kopplin, C.S. Bridge the gap: Consumers' purchase intention and behavior regarding sustainable clothing. J. Clean. Prod. 2021, 278, 123882. [CrossRef]

47. Cerri, J.; Testa, F.; Rizzi, F. The more I care, the less I will listen to you: How information, environmental concern and ethical production influence consumers' attitudes and the purchasing of sustainable products. J. Clean. Prod. 2018, 175, 343-353. [CrossRef]

48. Weisstein, F.L.; Asgari, M.; Siew, S.-W. Price presentation effects on green purchase intentions. J. Prod. Brand Manag. 2014, 23, 230-239. [CrossRef]

49. Sana, S.S. Price competition between green and non-green products under corporate social responsible firm. J. Retail. Consum. Serv. 2020, 55, 102118. [CrossRef]

50. Orsi, L.; Voege, L.L.; Stranieri, S. Eating edible insects as sustainable food? Exploring the determinants of consumer acceptance in Germany. Food Res. Int. 2019, 125, 108573. [CrossRef] [PubMed]

51. Wang, B.; Yuan, Z.; Liu, X.; Sun, Y.; Zhang, B.; Wang, Z. Electricity price and habits: Which would affect household electricity consumption? Energy Build. 2021, 240, 110888. [CrossRef]

52. Anderhofstadt, B.; Spinler, S. Factors affecting the purchasing decision and operation of alternative fuel-powered heavy-duty trucks in Germany-A Delphi study. Transp. Res. Part D Transp. Environ. 2019, 73, 87-107. [CrossRef]

53. Kahupi, I.; Hull, C.E.; Okorie, O.; Millette, S. Building competitive advantage with sustainable products-A case study perspective of stakeholders. J. Clean. Prod. 2021, 289, 125699. [CrossRef]

54. Senturk, G.; Dumludag, D. An evaluation of the effect of plastic bag fee on consumer behavior: Case of Turkey. Waste Manag. 2021, 120, 748-754. [CrossRef] [PubMed]

55. Ahlström, R.; Gärling, T.; Thøgersen, J. Affluence and unsustainable consumption levels: The role of consumer credit. Clean. Responsible Consum. 2020, 1, 100003. [CrossRef]

56. Norman, D. The Design of Everyday Things; Basic Books: New York, NY, USA, 2016.

57. Kimmel, A.J. People and Products: Consumer Behavior and Product Design; Chapter 3; Routledge: London, UK, 2015.

58. Franciosi, C.; Voisin, A.; Miranda, S.; Riemma, S.; Iung, B. Measuring maintenance impacts on sustainability of manufacturing industries: From a systematic literature review to a framework proposal. J. Clean. Prod. 2020, 260, 121065. [CrossRef]

59. Harich, J. Change resistance as the crux of the environmental sustainability problem. Syst. Dyn. Rev. 2010, 26, 35-72. [CrossRef]

60. Cooper, T. Longer Lasting Products: Alternatives to the Throwaway Society; Routledge: New York, NY, USA, 2016.

61. Du, Q.; Han, X.; Li, Y.; Li, Z.; Xia, B.; Guo, X. The energy rebound effect of residential buildings: Evidence from urban and rural areas in China. Energy Policy 2021, 153, 112235. [CrossRef]

62. Siderius, T.; Poldner, K. Reconsidering the Circular Economy Rebound effect: Propositions from a case study of the Dutch Circular Textile Valley. J. Clean. Prod. 2021, 293, 125996. [CrossRef]

63. Favi, C.; Marconi, M.; Germani, M.; Mandolini, M. A design for disassembly tool oriented to mechatronic product demanufacturing and recycling. Adv. Eng. Inform. 2019, 39, 62-79. [CrossRef]

64. Wan, C.; Shen, G.Q.; Yu, A. The role of perceived effectiveness of policy measures in predicting recycling behaviour in Hong Kong. Resour. Conserv. Recycl. 2014, 83, 141-151. [CrossRef]

65. Chen, F.; Chen, H.; Yang, J.; Long, R.; Li, Q. Impact of Information Intervention on the Recycling Behavior of Individuals with Different Value Orientations-An Experimental Study on Express Delivery Packaging Waste. Sustainability 2018, $10,3617$. [CrossRef]

66. Zamani, B.; Sandin, G.; Peters, G. Life cycle assessment of clothing libraries: Can collaborative consumption reduce the environmental impact of fast fashion? J. Clean. Prod. 2017, 162, 1368-1375. [CrossRef]

67. Shittu, O.S.; Williams, I.D.; Shaw, P.J. Global E-waste management: Can WEEE make a difference? A review of e-waste trends, legislation, contemporary issues and future challenges. Waste Manag. 2021, 120, 549-563. [CrossRef] [PubMed] 
68. Taufik, D.; Reinders, M.; Molenveld, K.; Onwezen, M.C. The paradox between the environmental appeal of bio-based plastic packaging for consumers and their disposal behaviour. Sci. Total. Environ. 2020, 705, 135820. [CrossRef] [PubMed]

69. Roos, S.; Sandin, G.; Zamani, B.; Peters, G.; Svanström, M. Will Clothing Be Sustainable? Clarifying Sustainable Fashion. In Textile Science and Clothing Technology; Gabler: Wiesbaden, Germany, 2017; pp. 1-45.

70. Grazzini, L.; Acuti, D.; Aiello, G. Solving the puzzle of sustainable fashion consumption: The role of consumers' implicit attitudes and perceived warmth. J. Clean. Prod. 2021, 287, 125579. [CrossRef]

71. Mugge, R.; Schoormans, J.P.L.; Schifferstein, H.N.J. Design Strategies to Postpone Consumers' Product Replacement: The Value of a Strong Person-Product Relationship. Des. J. 2005, 8, 38-48. [CrossRef]

72. Zhang, X.; Gong, X.; Jiang, J. Dump or recycle? Nostalgia and consumer recycling behavior. J. Bus. Res. 2021, 132, 594-603. [CrossRef]

73. Khadilkar, P.R.; Cash, P. Understanding behavioural design: Barriers and enablers. J. Eng. Des. 2020, 31, 508-529. [CrossRef]

74. Gutowski, T.G. A Critique of Life Cycle Assessment; Where Are the People? Procedia CIRP 2018, 69, 11-15. [CrossRef]

75. D'Anna, W.; Cascini, G. Supporting sustainable innovation through TRIZ system thinking. Procedia Eng. 2011, 9, 145-156. [CrossRef]

76. Becattini, N.; Borgianni, Y.; Cascini, G.; Rotini, F. A TRIZ-based CAI framework to guide engineering students towards a broad-spectrum investigation of inventive technical problems. Int. J. Eng. Educ. 2013, 29, 318-333.

77. Livotov, P.; Sekaran, A.P.C.; Mas'Udah; Law, R.; Reay, D.; Sarsenova, A.; Sayyareh, S. Eco-innovation in process engineering: Contradictions, inventive principles and methods. Therm. Sci. Eng. Prog. 2019, 9, 52-65. [CrossRef]

78. Maccioni, L.; Borgianni, Y. Investigating the Value Perception of Specific TRIZ Solutions Aimed to Reduce Product's Environmental Impact. In Proceedings of the Service Science and Knowledge Innovation; Gabler: Wiesbaden, Germany, 2019; pp. $282-294$.

79. Russo, D.; Spreafico, C. TRIZ-Based Guidelines for Eco-Improvement. Sustainability 2020, 12, 3412. [CrossRef]

80. Maccioni, L.; Borgianni, Y. An Ideality-Based Map to Describe Sustainable Design Initiatives. In Proceedings of the Service Science and Knowledge Innovation; Gabler: Wiesbaden, Germany, 2021; pp. 3-13.

81. Borgianni, Y.; Fiorineschi, L.; Frillici, F.S.; Rotini, F. The process for individuating TRIZ Inventive Principles: Deterministic, stochastic or domain-oriented? Des. Sci. 2021, 7, 12. [CrossRef]

82. Spreafico, C. Quantifying the advantages of TRIZ in sustainability through life cycle assessment. J. Clean. Prod. 2021, $303,126955$. [CrossRef] 